Jurnal Ilmiah Kesehatan Sandi Husada
https://akper-sandikarsa.e-journal.id/JIKSH
Volume 10| Nomor 2| Desember|2021
e-ISSN: 2654-4563 dan p-ISSN: 2354-6093
DOI:10.35816/jiskh.v10i2.506

\title{
Pengaruh Seminar Online terhadap Pengetahuan Masyarakat tentang COVID-19 dan Adaptasi Kebiasaan Baru
}

Mariatul Fadilah', ${ }^{1}$ Pariyana $^{2}$, Sisi Melansi ${ }^{3}$, Ayu Kartika Putri ${ }^{4}$

$1^{*}$ Konsil Kedokteran Indonesia, Indonesia

2Bagian IKM-IKK, Fakultas Kedokteran, Universitas Sriwijaya, Sumatera Selatan

${ }^{3}$ Fakultas Kedokteran, Universitas Sriwijaya, Sumatera Selatan

\begin{tabular}{|c|c|}
\hline Article Info & Abstract \\
\hline $\begin{array}{l}\text { Article History: } \\
\text { Received } \\
\text { 2021-06-31 } \\
\text { Accepted } \\
\text { 2021-08-31 } \\
\text { Published } \\
\text { 2021-12-31 }\end{array}$ & $\begin{array}{l}\text { Pendahuluan; adanya tuntutan ekonomi membuat pemerintah } \\
\text { berusaha mencari solusi dengan memberlakukan suatu tatanan } \\
\text { kehidupan yang baru yaitu adaptasi kebiasaan baru. Tujuan; } \\
\text { mengetahui pengaruh seminar online terhadap pengetahuan } \\
\text { masyarakat tentang COVID-19 dan adaptasi kebiasaan baru. } \\
\text { Metode; menggunakan desain quasi eksperimental pre dan } \\
\text { posttest. Sampel dalam penelitian peserta yang mengisi kuesioner } \\
\text { pretest dan posttest sebanyak } 181 \text { responden dan data tersebut di } \\
\text { analisis univariat, bivariat dan Uji Wilcoxon menggunakan } \\
\text { program SPSS.Hasil; menunjukkan bahwa mayoritas responden } \\
\text { memiliki median usia } 25 \text { tahun, jenis kelamin perempuan } \\
\text { (55,2\%), pendidikan terakhir berupa S1/ D4 (65,2\%), dan } \\
\text { sebagian besar memiliki tingkat pengetahuan cukup (42,5\%), } \\
\text { baik (42,5\%. Kesimpulan; seminar online tidak memiliki } \\
\text { pengaruh yang bermakna secara statistik dalam meningkatkan } \\
\text { pengetahuan masyarakat mengenai COVID-19 dan AKB namun } \\
\text { masih bisa dipertimbangkan untuk menjadi alternatif yang dipilih } \\
\text { pada karakteristik responden tertentu. } \\
\text { Introduction; the existence of economic demands made the } \\
\text { government try to find a solution by enacting a new order of life, } \\
\text { namely the adaptation of new habits. Aim; knowing the effect of } \\
\text { online seminars on people's knowledge about COVID-19 and the } \\
\text { adaptation of new habits. Method; using a quasi-experimental pre } \\
\text { and post-test design. The sample in the study of participants who } \\
\text { filled out the pretest and posttest questionnaires were } 181 \\
\text { respondents and the data were analyzed by univariate, bivariate, } \\
\text { and Wilcoxon tests using the SPSS program. Results; shows that } \\
\text { the majority of respondents have a median age of } 25 \text { years, } \\
\text { gender is female (55.2\%), the latest education is S1/D4 (65.2\%), } \\
\text { and most have a sufficient level of knowledge ( } 42.5 \% \text {, good } \\
\text { ( } 42,5 \% \text { Conclusion: online seminars do not have a statistically } \\
\text { significant effect in increasing public knowledge about COVID- } \\
19 \text { and IMR but can still be considered as an alternative chosen } \\
\text { for certain respondent characteristics. }\end{array}$ \\
\hline $\begin{array}{l}\text { Corresponding author } \\
\text { Email }\end{array}$ & $\begin{array}{l}\text { ariatul Fadilah } \\
\text { ariatulfadilah4@gmail.com }\end{array}$ \\
\hline
\end{tabular}


Jurnal Ilmiah Kesehatan Sandi Husada

Volume 10 Nomor 2 Desember 2021

\section{Pendahuluan}

Pada akhir tahun 2019 tepatnya bulan Desember, Kota Wuhan (China) melaporkan penemuan wabah penyakit baru yang menyerang sistem pernapasan manusia. Hal ini menjadi perhatian dunia karena penularan yang cepat sehingga pada tanggal 30 Januari dinyatakan sebagai kegawatdaruratan kesehatan masyarakat dan pada 12 Maret 2020 dinyatakan sebagai pandemic global oleh World Health Organization (WHO, 2020). Penyakit ini disebabkan oleh viru baru yang disebut sebagai virus corona karena strukturnya seperti mahkota dan dianggap masih satu family dengan Coronaviridae. Virus ini menyerang sistem pernapasan sehingga umumnya menimbulkan gejala seperti gejala flu dan dapat menjadi berat (pneumonia, bahkan kematian) terutama pada individu memiliki komorbid seperti hipertensi, diabetes mellitus, perokok aktif, dan laki-laki. Penyakit ini kemudian disebut coronavirus disease 2019 (COVID-19) atau Severe Acute Respiratory Syndrome-Coronavirus 2 (SARS-CoV-2) karena kemiripan gejalanya dengan SARS (Huang et al., 2020).

Penyakit ini memiliki penularan yang sangat cepat melalui kontak langsung dan droplet. Masa inkubasi virus ini adalah 4-14 hari pada manusia. Sampai tanggal 17 Oktober 2020, jumlah kasus terkonfirmasi positif masih bertambah dengan total 39.196.259 kasus di dunia, total kematian sebanyak 1.101.298 kasus dan Amerika merupakan negara yang memiliki kasus konfirmasi positif tertinggi di dunia. Data kasus konfirmasi positif di Indonesia sampai tanggal 17 Oktober 2020 mencapai 353.461 kasus dan kasus kematian sebanyak 12.347 kasus. Jumlah kasus positif di Indonesia masih semakin bertambah bahkan mencapai sekitar 4.000 kasus terkonfirmasi positif setiap hari (Direktorat Jenderal Pencegahan dan Pengendalian Penyakit (P2P), 2020). Penyakit ini merupakan penyakit baru yang memiliki tingkat penularan sangat cepat pada manusia namun belum ditemukan obat spesifik untuk mengatasinya sehingga tindakan pencegahan merupakan hal penting untuk memutus rantai penularan COVID-19. Pemerintah menggalakkan masyarakat untuk menerapkan $3 \mathrm{M}$ yaitu mencuci tangan dengan sabun minimal 20 menit, memakai masker saat akan pergi keluar rumah, dan menjaga jarak minimal 1 meter. Untuk menata kehidupan kembali produktif seperti sebelum adanya COVID-19, pemerintah juga menyatakan untuk memulai adaptasi kebiasaan baru (AKB) dengan menerapkan protokol kesehatan sebagai bentuk pencegahan infeksi COVID-19 (Commission, 2019).

AKB dianggap sebagai pilihan yang baik untuk menyeimbangkan ekonomi dan kesehatan masyarakat. Penerapan AKB juga dilakukan pada semua sektor kehidupan tak terkecuali perkantoran. Salah satu upaya untuk memberikan edukasi kepada masyarakat adalah dengan memberikan penyuluhan kesehatan, namun sulit dilakukan jika secara konvensional (secara langsung), sehingga seminar online dapat dipilih sebagai alternatif (Gon \& Rawekar, 2017). Penelitian ini bertujuan mengetahui perubahan pengetahuan masyarakat mengenai COVID-19 dan AKB di perkantoran dan perubahan rerata tingkat pengetahuan setelah dilakukan promosi kesehatan dalam bentuk seminar online.

\section{Metode}

Penelitian ini menggunakan desain quasi eksperimental pre dan post. Populasi dalam penelitian ini adalah 257 peserta yang bergabung dalam seminar online dan subjek penelitian (sampel) pada penelitian ini adalah peserta yang mengikuti seminar online dan mengisi kuesioner sebelum dan sesudah seminar. Penelitian ini dilakukan pada bulan September 2020 menggunakan metode total sampling kepada seluruh peserta yang memenuhi kriteria inklusi dan tidak memiliki kriteria eksklusi. Penelitian ini menggunakan data primer kuesioner yang telah diisi sebelum dan sesudah seminar online mengenai profil fisik, demografik, dan pengetahuan responden tentang COVID-19 dan Adaptasi Kebiasaan Baru (AKB). Data tersebut dianalisis menggunakan program SPSS 25.0. Analisis univariat dilakukan untuk mengetahui sebaran frekuensi karakteristik responden berdasarkan usia, jenis kelamin, pekerjaan, tingkat pendidikan terakhir, dan pengetahuan. Analisis bivariat dilakukan untuk mengetahui perubahan pengetahuan rerata 
Mariatul Fadila, dkk. Pengaruh Seminar Online terhadap......

responden baik sebelum maupun setelah mengikuti seminar online mengenai COVID-19 dan Adaptasi Kebiasaan Baru (AKB).

\section{Hasil Dan Pembahasan}

Tabel 1

Karakteristik Jawaban Benar tiap Pertanyaan

\begin{tabular}{lcc}
\hline \multicolumn{1}{c}{ Pertanyaan } & $\begin{array}{c}\text { Pre } \\
\mathbf{n} \\
(\mathbf{\%})\end{array}$ & $\begin{array}{c}\text { Post } \\
\mathbf{n} \\
(\mathbf{\%})\end{array}$ \\
\hline $\begin{array}{l}\text { Apakah anda tahu gejala dari org yg terinfeksi COVID-19? } \\
\text { (1) }\end{array}$ & $\begin{array}{c}147 \\
(81,2 \%)\end{array}$ & $146(80,7 \%)$ \\
\hline $\begin{array}{l}\text { Apakah seseorang yang tanpa gejala dapat terinfeksi } \\
\text { COVID-19? (2) }\end{array}$ & $157(86,7 \%)$ & $143(79 \%)$ \\
\hline $\begin{array}{l}\text { Apakah anda mengetahui makna dibuat himbauan untuk } \\
\text { mencuci tangan, menjaga jarak, memakai masker? (3) }\end{array}$ & $134(74 \%)$ & $143(79 \%)$ \\
\hline $\begin{array}{l}\text { Saya merasa pada adaptasi kebiasaan baru atau "new } \\
\text { normal" diberlakukan protokol pencegahan COVID-19 di } \\
\text { kantor merupakan hal 1ng penting (4) }\end{array}$ & $144(79,6 \%)$ & $143(79 \%)$ \\
\hline $\begin{array}{l}\text { Dengan diterapkannya "work from office" atau bekerja dari } \\
\text { kantor saya bisa berkumpul serta makan bersama dengan } \\
\text { teman tanpa menjaga jarak (5) }\end{array}$ & $110(60,8 \%)$ & $144(79,6 \%)$ \\
\hline $\begin{array}{l}\text { Apabila terasa gerah saat berada di kantor saya boleh } \\
\text { membuka maskernya (6) }\end{array}$ & $87(48,1 \%)$ & $44(24,3 \%)$ \\
\hline $\begin{array}{l}\text { Penularan COVID-19 di kantor lebih mudah terjadi karena } \\
\text { ruangan ber-AC (7) }\end{array}$ & $132(72,9 \%)$ & $131(72,4 \%)$ \\
\end{tabular}

\section{Sumber: data diolah}

Sebelum seminar, pertanyaan kedua mengenai penularan COVID-19 pada orang tanpa gejala adalah paling banyak dijawab benar oleh responden $(86,7 \%)$. Setelah seminar, terdapat 1 pertanyaan yang berhasil dijawab benar oleh $80,7 \%$ peserta, yakni pertanyaan pertama. Tidak terdapat peningkatan jumlah jawaban benar pada peserta setelah mengikuti seminar online.

Grafik 1

Frekuensi Tingkat Pengetahuan COVID-19 dan AKB pada Responden Sebelum dan Sesudah Seminar Online

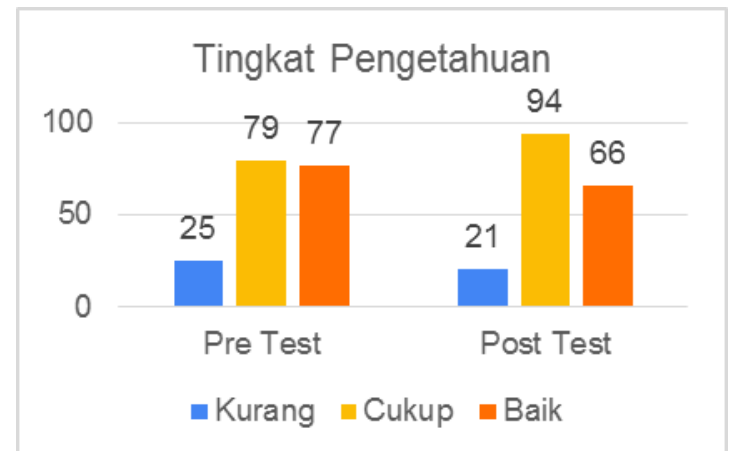

Hasil analisis pengetahuan responden sebelum seminar online didapatkan, sebagian besar responden memiliki tingkat pengetahuan cukup $(42,5 \%)$ dan baik $(42,5 \%)$ mengenai COVID-19 dan adaptasi kebiasaan baru (AKB). Setelah mengikuti seminar online, terdapat peningkatan pada tingkat pengetahuan responden kategori cukup dari 42,5\% menjadi 51,9\% dan terjadi penurunan tingkat pengetahuan responden kategori kurang, yaitu dari 13,8\% menjadi 11,6\%. 
Jurnal Ilmiah Kesehatan Sandi Husada

Volume 10 Nomor 2 Desember 2021

Tabel 3.

Uji Normalitas Data Pengetahuan

\begin{tabular}{clcc}
\hline Pengetahuan & \multicolumn{3}{c}{ Kolmogorov-Smirnov } \\
\cline { 2 - 4 } & Statistic & $D f$ & Sig. \\
\hline Pretest & 0.193 & 181 & 0,000 \\
Posttest & 0.181 & 181 & 0,000 \\
\hline
\end{tabular}

\section{Sumber: data diolah}

Hasil uji normalitas data pengetahuan responden mengenai COVID-19 dan Adaptasi

Kebiasaan Baru (AKB) sebelum dan sesudah mengikuti seminar online menggunakan uji Kolmogorov-Smirnov diperoleh bahwa bahwa pengetahuan sebelum menunjukkan $\mathrm{p}$ value $=$ $0,000<0,05$ yang berarti data berdistribusi tidak normal. Pengetahuan setelah menunjukkan $p$ value $=0,000<0.05$ yang berarti data berdistribusi tidak normal, sehingga digunakan uji wilcoxon untuk melakukan perbandingan pengetahuan responden sebelum dan sesudah mengikuti seminar online.

Tabel 4.

Perbandingan menggunakan Uji Wilcoxon Nilai Pengetahuan Responden Sebelum dan Sesudah Seminar Online

\begin{tabular}{|c|c|c|}
\hline Pengetahuan & $\begin{array}{l}\text { Rerata Nilai } \pm \\
\text { S.b }\end{array}$ & $p$ value* \\
\hline $\begin{array}{l}\text { Sebelum } \\
\text { seminar }\end{array}$ & $5,03 \pm 1,320$ & 0.256 \\
\hline $\begin{array}{l}\text { Sesudah } \\
\text { seminar }\end{array}$ & $4,94 \pm 1,175$ & \\
\hline
\end{tabular}

Uji Wilcoxon p value >0,05

Hasil analisis menggunakan uji Wilcoxon didapatkan $p$ value $=0.256>0,05$ yang berarti tidak terdapat perubahan rerata pengetahuan yang signifikan antara pengetahuan responden sebelum dan sesudah mengikuti seminar online. Hal ini menunjukkan bahwa seminar online tidak memiliki pengaruh yang bermakna secara statistik dalam peningkatan pengetahuan masyarakat awam mengenai COVID-19 dan adaptasi kebiasaan baru (AKB).

\section{Pembahasan}

Berdasarkan sebaran data usia, responden yang mengikuti seminar online dan mengisi kuesioner baik sebelum dan sesudah seminar online didapatkan median usia responden adalah 25 tahun. Penelitian ini sama halnya dengan survei yang dilakukan oleh Asosiasi Penyelenggaraan Jasa Internet Indonesia yang menyatakan $49,52 \%$ dari pengguna total internet yang mengakses gadget adalah kelompok usia 19-34 tahun.8 Sebaran data jenis kelamin menunjukkan 55,2\% responden adalah perempuan namun tidak berbeda jauh dengan jumlah responden laki-laki. Penelitian ini serupa dengan penelitian yang dilakukan dengan menyebarkan kuesioner secara online untuk mengetahui tingkat pengetahuan masyarakat di Indonesia mengenai COVID-19, hasil menyatakan bahwa 72,1\% responden adalah perempuan (Fadilah et al., 2021). Distribusi frekuensi data pendidikan terakhir responden sebagian besar adalah S1/ D4 (65,2\%). Penelitian ini mirip dengan hasil penelitian yang dilakukan secara online untuk menilai pengetahuan, sikap, dan perilaku masyarakat terhadap kebijakan pembatasan sosial di Indonesia dan didapatkan sebagian besar responden $(54,72 \%)$ memiliki tingkat pendidikan terakhir berupa lulusan sarjana, magister, dan doctoral.

Berdasarkan hasil penelitian ini, didapatkan tingkat pengetahuan awal responden sebelum mengikuti seminar online sebagian masuk dalam kategori tingkat pengetahuan yang cukup (42,5\%) dan baik (42,5\%) mengenai COVID-19 dan AKB. Setelah mengikuti seminar online, responden yang memiliki tingkat pengetahuan cukup mengalami peningkatan menjadi 51,9\% dan 
Mariatul Fadila, dkk. Pengaruh Seminar Online terhadap......

pada responden yang memiliki tingkat pengetahuan kurang mengalami penurunan dari $13,8 \%$ menjadi $11,6 \%$. Hal ini menunjukkan bahwa tingkat pengetahuan awal masyarakat sebelum diadakan seminar online cukup baik sama halnya dengan yang dinyatakan oleh penelitian Yanti bahwa distribusi responden yang memiliki tingkat pengetahuan baik adalah 99\% dan kurang baik hanya 1\% (Yanti et al., 2020). Hasil penelitian ini juga serupa dengan penelitian yang dilakukan oleh Maulida dan menunjukkan bahwa komunikasi kesehatan dapat merubah perilaku seseorang, namun dibutuhkan waktu, strategi dan pendekatan tertentu untuk mencapai tujuan tersebut (Maulida \& Nugraheni, 2020). Menurut (Suprapto,2021) bahwa edukasi dapat meningkatkan pengetahuan terhadap dalam pencegahan Covid-19.

Analisis data berpasangan antara tingkat pengetahuan masyarakat sebelum dan sesudah mengikuti seminar online didapatkan nilai $\mathrm{p}$ value $=0.256>0,05 \mathrm{y}$ ang berarti tidak terdapat perubahan rerata pengetahuan yang signifikan secara statistic antara pengetahuan responden sebelum dan sesudah mengikuti seminar online. Artinya penelitian ini menyatakan bahwa seminar online tidak memiliki pengaruh yang bermakna dalam meningkatkan pengetahuan masyarakat mengenai COVID-19 dan AKB. Hasil penelitian ini sebenarnya bertentangan dengan hipotesis yang menyatakan adanya peningkatan rerata pengetahuan responden sesudah mengikuti seminar online. Hal ini dapat terjadi karena responden penelitian ini pada dasarnya sudah memiliki tingkat pengetahuan yang kategori cukup dan baik, hanya $13,8 \%$ saja responden yang masuk kategori kurang. Persentase responden dengan kategori kurang mengalami penurunan setelah mengikuti seminar online menjadi 11,6\%. Artinya memang ada pengaruh seminar online namun tidak begitu terlihat secara statistik karena sebaran data pendidikan terakhir responden sebagian besar adalah lulusan S1/D4. Latar belakang pendidikan ini sangat membantu untuk penerapan adaptasi kebiasaan baru di perkantoran untuk upaya mencegah dan mengendalikan penularan COVID-19 di tempat kerja.

Menurut hasil penelitian (Parhizkar et al., 2013) menunjukkan bahwa kurangnya pengetahuan, informasi tentang tes Pap smear, dan komunikasi yang buruk. Pemberian pengetahuan yang spesifik, valid, dan tepat sasaran dapat meningkatkan perilaku usaha pencegahan masyarakat terhadap infeksi COVID-19 (Moudy \& Syakurah, 2020). New normal atau dikenal dengan kenormalan baru merupakan langkah awal langkah awal dalam mengembalikan produktivitas masyarakat yang sebelumnya terbatas akibat penerapan pembatasan skala besar-besaran (PSBB) (Rizqullah \& Syakurah, 2020). Kenormalan baru juga mengharuskan masyarakat untuk beradaptasi dengan melakukan aktivitas sehari-hari namun tetap menjalankan protokol kesehatan demi pemulihan ekonomi yang sempat lumpuh atau mengalami penurunan produktivitas selama pemberlakuan PSBB. Pemerintah pusat melalui Kementerian Kesehatan Republik Indonesia (Kemenkes RI) mengeluarkan; Keputusan Menteri Kesehatan (Kepmenkes) No. HK.01.07/Menkes/328/2020 tentang Panduan Pencegahan dan Pengendalian COVID-19 di Tempat Kerja Perkantoran dan Industri dengan tujuan mendukung keberlangsungan usaha walaupun pandemi belum berakhir. Surat edaran nomor HK.02.01/MENKES/335/2020 tentang Protokol Pencegahan Penularan COVID-19 di Tempat Kerja Sektor Jasa dan Perdagangan (Area Publik) memberi kesempatan pada sektor perkantoran khususnya bagi perusahaan-perusahaan untuk mulai menerapkan kerja di kantor lagi seperti biasa dengan menerapkan adaptasi kebiasaan baru di era pandemi COVID-19 yang belum berakhir. Hal ini membuat masyarakat atau perkantoran meninggalkan bekerja dari rumah (Work From Home) yang sebelumnya ditetapkan oleh pemerintah (Kemenkes RI, 2020).

Penerapan adaptasi kebiasaan baru (AKB) di Indonesia telah dirancang dengan matang dan diberikan himbauan untuk tetap melakukan protokol kesehatan bagi seluruh masyarakat walaupun sudah kembali bekerja di kantor lagi. Namun, tampaknya masih banyak juga masyarakat yang persepsi dan sikapnya yang tidak mengindahkan himbauan pemerintah akibat banyak beredar di media sosial tentang teori konspirasi terkait pandemi COVID-19 (Lin et al., 2020). Bahwa ada hubungan antara stres dengan motivasi belajar diera pandemic Covid-19 (Savira et al., 2021). Menurut (Blanchette \& Richards, 2010) bahwa berfokus pada beberapa 
Jurnal Ilmiah Kesehatan Sandi Husada

Volume 10 Nomor 2 Desember 2021

mekanisme konstituen yang terlibat dalam interpretasi, penilaian, pengambilan keputusan dan penalaran menyediakan cara untuk menghubungkan beberapa temuan yang beragam di lapangan.

Suatu penelitian di Indonesia yang melakukan analisis perilaku masyarakat Indonesia dalam menghadapi COVID-19 ternyata melaporkan bahwa perilaku yang ditampilkan oleh orang yang tidak mematuhi himbauan pemerintah seperti masyarakat di Indonesia didasari oleh bias kognitif. Bias kognitif ini sendiri adalah jenis kesalahan dalam berpikir yang terjadi ketika seseorang memproses dan menafsirkan informasi di dunia di sekitar mereka (Buana, 2020). Hal ini menyebabkan pendidikan kesehatan perlu dilakukan sebagai upaya meningkatkan pengetahuan masyarakat tentang kesehatan (Bodnar et al., 2016). Pemilihan media online untuk promosi kesehatan dikarenakan kemudahan dalam berinteraksi antara peserta dan narasumber pada seminar. Fitur yang ada (gambar, video, ataupun rekaman suara) dalam aplikasi seperti WhatsApp juga cukup lengkap untuk memudahkan penyampaian informasi sehingga diharapkan dapat memberikan intervensi yang baik dalam rangka meningkatkan pengetahuan masyarakat setelah mengikuti seminar online (Gon \& Rawekar, 2017). Menurut (Syamson et al., 2021) bahwa ada perbedaan yang signifikan frekuensi kecemasan tentang COVID-19 sebelum intervensi dan setelah intervensi pendidikan kesehatan. Bahwa semakin lama seseorang menggunakan gadget di malam hari, semakin sulit untuk tertidur. Gejala susah tidur biasa disebut insomnia (A'yun et al., 2018).

\section{Simpulan Dan Saran}

Bahwa seminar online tidak berpengaruh secara signifikan namun masih dapat menjadi alternatif metode promosi kesehatan yang dipilih dalam meningkatkan pengetahuan masyarakat mengenai COVID-19 dan AKB di masa pandemi. Upaya yang dapat dilakukan untuk meningkatkan pengetahuan masyarakat melalui seminar online adalah membuat video penjelasan singkat dan inovatif yang dapat disebarluaskan melalui sosial media.

\section{Daftar Rujukan}

A'yun, S. Q., Sri Darnoto, S. K. M., \& Windi Wulandari, S. K. M. (2018). Hubungan Lama Penggunaan Gadget Sebelum Tidur dengan Gejala Insomnia pada Mahasiswa Program Studi Kesehatan Masyarakat. Universitas Muhammadiyah Surakarta.

Blanchette, I., \& Richards, A. (2010). The influence of effect on higher-level cognition: A review of research on interpretation, judgment, decision making, and reasoning. Cognition \& Emotion, 24(4), 561-595.

Bodnar, T. W., Iyengar, J. J., Patil, P. V, \& Gianchandani, R. Y. (2016). Can a single interactive seminar durably improve knowledge and confidence of hospital diabetes management? Clinical Diabetes and Endocrinology, 2(1), 1-8.

Buana, D. R. (2020). Analisis perilaku masyarakat indonesia dalam menghadapi pandemi virus corona (Covid-19) dan kiat menjaga kesejahteraan jiwa. Salam: Jurnal Sosial Dan Budaya Syar-I, 7(3), 217-226.

Commission, W. M. H. (2019). Report of clustering pneumonia of unknown etiology in Wuhan City. Wuhan Municipal Health Commission: Wuhan City Health Committee.

Direktorat Jenderal Pencegahan dan Pengendalian Penyakit (P2P). (2020). Pedoman Pencegahan dan Pengendalian Coronavirus Disease (COVID-19). Kementerian Kesehatan RI.

Fadilah, M., Ningsih, W. I. F., Berlin, O., Wimaulia, A., Azlin, A., \& Syakurah, R. A. (2021). Pengaruh seminar online terhadap pengetahuan dalam meningkatkan imunitas untuk menghadapi covid-19 dan persepsi mengenai new normal pada masyarakat awam. JKESMAS: Jurnal Kesehatan Masyarakat, 6(2), 134-149.

Gon, S., \& Rawekar, A. (2017). Effectivity of e-learning through WhatsApp as a teachinglearning tool. MVP Journal of Medical Sciences, 4(1), 19-25. 
Mariatul Fadila, dkk. Pengaruh Seminar Online terhadap......

Huang, C., Wang, Y., Li, X., Ren, L., Zhao, J., Hu, Y., Zhang, L., Fan, G., Xu, J., \& Gu, X. (2020). Clinical features of patients infected with 2019 novel coronavirus in Wuhan, China. The Lancet, 395(10223), 497-506.

Kemenkes RI. (2020). KMK Nomor Hk.01.07/Menkes/328/2020 Tentang Panduan Pencegahan Dan Pengendalian Coronavirus Disease 2019 (Covid-19) Di Tempat Kerja. Menteri Kesehatan Republik Indonesia, 2019, 1-39.

Lin, Y.-H., Liu, C.-H., \& Chiu, Y.-C. (2020). Google searches for the keywords of "wash hands" predict the speed of national spread of COVID-19 outbreak among 21 countries. Brain, Behavior, and Immunity, 87, 30-32.

Maulida, H., \& Nugrahenti, M. C. (2020). Komunikasi Kesehatan Perilaku Hidup Sehat\# JSR Di Media Sosial. Jurnal Teras Kesehatan, 3(1), 18-32.

Moudy, J., \& Syakurah, R. A. (2020). Pengetahuan terkait usaha pencegahan Coronavirus Disease (COVID-19) di Indonesia. Hygeia Journal of Public Health Research and Development, 4(3), 333-346.

Parhizkar, S., Latiff, L. A., \& Afshari, M. (2013). Disseminating cervical cancer knowledge: Impact of a public seminar. Int J Learn Dev, 3, 203-211.

Rizqullah, M. F., \& Syakurah, R. A. (2020). Public Search Interest Analysis on Indonesian COVID-19 Containment Policy. Jurnal Kebijakan Kesehatan Indonesia: JKKI, 9(3), 147153.

Savira, L., Setiawati, O., Husna, I., \& Pramesti, W. (2021). Relationship between Stress and Student Motivation during the Covid-19 Pandemic. Jurnal Ilmiah Kesehatan Sandi Husada, 10(1 SE-Articles). https://doi.org/10.35816/jiskh.v10i1.577

Suprapto, S. (2021). Edukasi Perilaku Hidup Bersih dan Sehat dan Pemberian Sembako Era Pandemi Covid-19: Suprapto. CARADDE: Jurnal Pengabdian Kepada Masyarakat, 3(3). https://doi.org/https/doi.org/10.31960/caradde.v3i3.624

Syamson, M., Fattah, A., \& Nurdin, S. (2021). Effect of Health Education on Elderly Anxiety About Coronavirus Disease (Covid 19) Transmission. Jurnal Ilmiah Kesehatan Sandi Husada, 10(1 SE-Articles). https://doi.org/10.35816/jiskh.v10i1.576

WHO. (2020). Novel Coronavirus.

Yanti, B., Mulyadi, E., Wahiduddin, W., Novika, R. G. H., Arina, Y. M. D., Martani, N. S., \& Nawan, N. (2020). Community knowledge, attitudes, and behavior towards social distancing policy as prevention transmission of COVID-19 in Indonesia. Jurnal Administrasi Kesehatan Indonesia, 8, 4-14. 